\title{
Extra-gastrointestinal stromal tumor arising in the lesser omentum with a platelet- derived growth factor receptor alpha (PDGF RA) mutation: a case report and literature review
}

Kohei Kanamori ${ }^{1}$, Yukinori Yamagata ${ }^{1 *} \mathbb{D}$, Yoshitaka Honma ${ }^{2}$, Keiichi Date ${ }^{1}$, Takeyuki Wada ${ }^{1}$, Tsutomu Hayashi $^{1}$, Sho Otsuki ${ }^{1}$, Shigeki Sekine ${ }^{3}$, Takaki Yoshikawa ${ }^{1}$, Hitoshi Katai ${ }^{1}$ and Toshiro Nishida ${ }^{1}$

\begin{abstract}
Background: Gastrointestinal stromal tumors (GIST) arising from sites other than the gastrointestinal (GI) tract, termed extra-gastrointestinal stromal tumors (EGIST), are rare. Among EGIST, those with platelet-derived growth factor receptor alpha (PDGFRA) mutations are even rarer, with only a few cases reported. About $80 \%$ of GIST has KIT mutations, and 10\% of GIST have PDGFRA mutations, which commonly affect the TK2 domain (exon 18). Among the exon 18 mutations, the D842V substitution is limited to gastric GIST. In EGIST, the degree of KIT and PDGFRA mutations varies on where the location of the tumor is, and it is suggested that omental EGIST is similar to gastric GIST. Adjuvant imatinib therapy is recommended for high-risk GIST; however, it is known that imatinib is less effective against GIST with a PDGFRA D842V mutation.
\end{abstract}

Case presentation: A 75-year-old man was referred to our hospital with an extrinsic tumor of the lesser curvature of the gastric body. Intraoperative findings showed a tumor located outside of the lesser omentum with no connection between the tumor and the gastric wall. The tumor was subsequently resected. Pathological examination indicated a GIST arising in the lesser omentum measuring $70 \mathrm{~mm}$ in its longer dimension. Because the tumor had a PDGFRA mutation (D842V substitution), imatinib was suspected to lack efficacy to the tumor. Thus, although the tumor was considered clinically to have a high risk of recurrence, adjuvant imatinib therapy was not indicated. The patient has been free of recurrence for 29 months since the surgery.

(Continued on next page)

\footnotetext{
*Correspondence: yuyamaga-tky@umin.ac.jp

${ }^{1}$ Gastric Surgery Division, National Cancer Center Hospital, 5-1-1 Tsukiji, Chuo-ku, Tokyo 104-0045, Japan

Full list of author information is available at the end of the article
}

(c) The Author(s). 2020 Open Access This article is licensed under a Creative Commons Attribution 4.0 International License, which permits use, sharing, adaptation, distribution and reproduction in any medium or format, as long as you give appropriate credit to the original author(s) and the source, provide a link to the Creative Commons licence, and indicate if changes were made. The images or other third party material in this article are included in the article's Creative Commons. licence, unless indicated otherwise in a credit line to the material. If material is not included in the article's Creative Commons licence and your intended use is not permitted by statutory regulation or exceeds the permitted use, you will need to obtain permission directly from the copyright holder. To view a copy of this licence, visit http://creativecommons.org/licenses/by/4.0/ The Creative Commons Public Domain Dedication waiver (http://creativecommons.org/publicdomain/zero/1.0/) applies to the data made available in this article, unless otherwise stated in a credit line to the data. 
(Continued from previous page)

Conclusion: We described a case of EGIST with a PDGFRA mutation arising in the lesser omentum. And we reviewed 57 cases of omental EGIST and showed that the clinicopathological characteristics and mutation status in omental EGIST were very similar to gastric GIST. In particular, PDGFAR D842V mutation rate in omental EGIST seemed as high as that in gastric GIST. These results suggested that omental EGIST is strongly related to gastric GIST, so the behavior of omental EGIST might be akin to gastric GIST. However, further studies are required to determine the prognosis and the necessity of adjuvant therapy for EGIST with a PDGFRA mutation.

Keywords: Extra-gastrointestinal stromal tumor, Omentum, Platelet-derived growth factor receptor alpha

\section{Background}

A gastrointestinal stromal tumor (GIST) is a relatively rare mesenchymal tumor of the gastrointestinal (GI) tract and is defined as a spindle cell or epithelioid neoplasm expressing a c-kit (CD117) immunophenotype, which is the tyrosine kinase (TK) component [1]. GIST usually has KIT mutations; however, a few have been reported with mutations in platelet-derived growth factor receptor alpha (PDGFRA) [2]. As mentioned above, GIST usually arises from the GI tract; however, entity GIST termed extra-gastrointestinal stromal tumors (EGIST) may arise in sites other than the GI tract. EGIS $\mathrm{T}$ represent less than $5 \%$ of all stromal tumors [3]. Similar to GIST arising in the GI tract, EGIST usually show
KIT mutations; however, EGIST with PDGFRA mutations appear to be rare. We report a case of EGIST with a PDGFRA mutation arising in the lesser omentum.

\section{Case presentation}

A 75-year-old man was referred to our hospital due to an abdominal mass detected by abdominal ultrasonography performed during a health check. He had histories of diabetes mellitus, hypertension, hyperlipidemia, and gallstones. Esophagogastroduodenoscopy (EGD) revealed a gently sloping protruding lesion with smooth surface mucosa, located anterior to the lesser curvature of the gastric body (Fig. 1a). Endoscopic ultrasonography (EUS) showed a submucosal hypoechoic tumor with a diameter
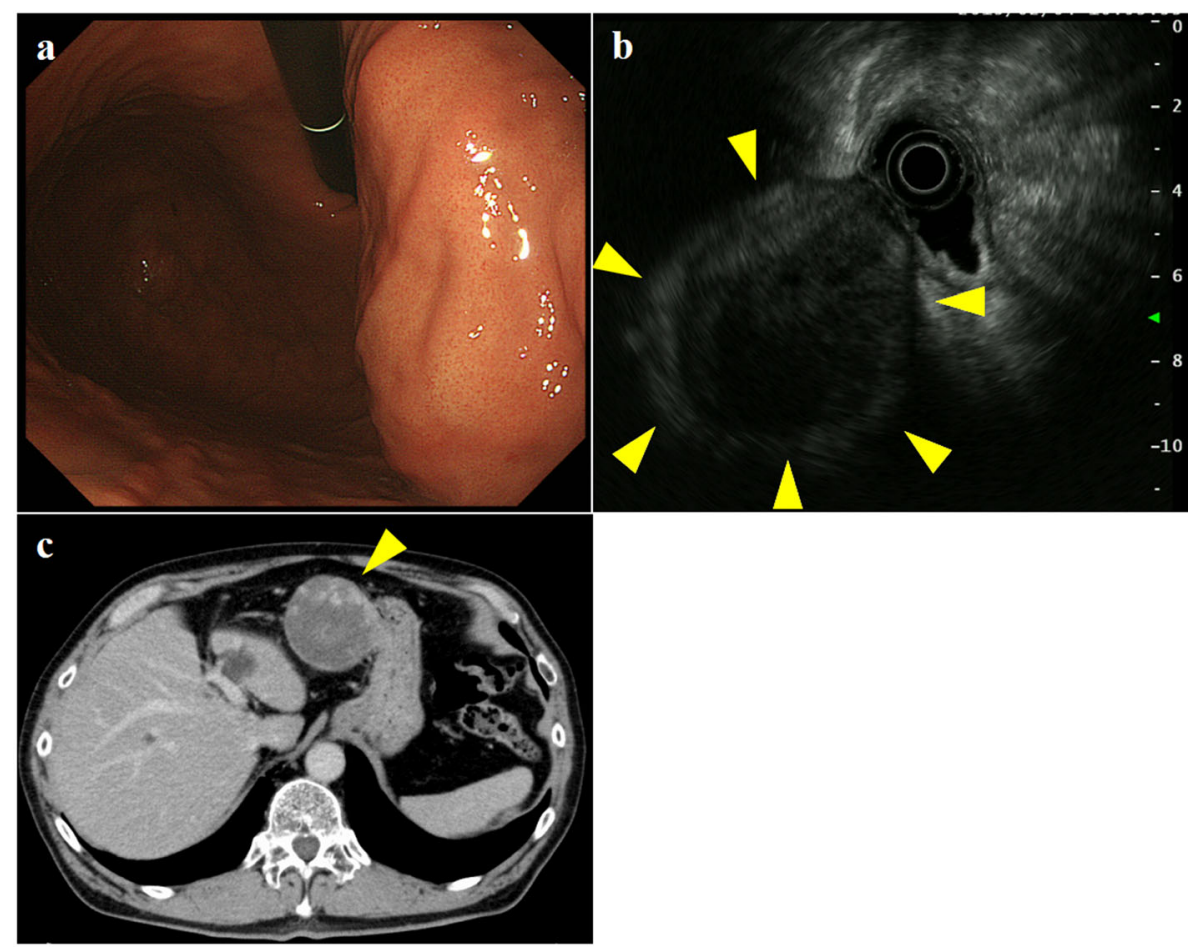

Fig. 1 Findings of preoperative examination. Esophagogastroduodenoscopy (EGD) revealed a gently sloping protruding lesion with smooth surface mucosa, located anterior to the lesser curvature of the gastric body. Ultrasonic endoscopy (EUS) showed an extra-stomach hypoechoic tumor with a diameter of $79 \times 58 \mathrm{~mm}$ that seemed to be connected to the smooth muscle layer of the stomach. Enhanced computed tomography (CT) revealed a solid tumor, 70-mm in diameter, which also seemed to be connected to the lesser curvature side of the gastric body 
of $79 \times 58 \mathrm{~mm}$ that seemed to be connected to the smooth muscle layer of the stomach (Fig. 1b). Due to the risk of dissemination, fine-needle aspiration biopsy was not performed. Enhanced computed tomography (CT) revealed a solid tumor, 70-mm in diameter, which also seemed to be connected to the lesser curvature side of the gastric body (Fig. 1c). Based on the results of EGD, EUS, and CT, we diagnosed this tumor as an extramural growth-type gastric submucosal tumor highly suspicious of GIST and planned surgical resection. Resection of the tumor through laparotomy was performed. The tumor was located at lesser omentum, measured 70 $\mathrm{mm}$ in its longer dimension, and was connected to the lesser omentum. The tumor was very close to the stomach; however, no connection was present between the tumor and gastric wall, and it could be resected without rupturing the pseudocapsule and did not contain any gastric component. The tumor had a smooth surface; the cut surface was solid with extensive hemorrhage and degeneration (Fig. 2). Histological examination showed the proliferation of epithelioid to spindle-shaped tumor cells with oval, rather uniform nuclei (Fig. 3a). The mitotic count was less than 1 per 50 high-power fields (HPFs). The tumor cells were immunohistochemically positive for KIT, CD34, and discovered on GIST-1 (DOG-1) but negative for S-100 and alpha-SMA (Fig. $3 b-d)$. The Ki-67 labeling index was 3.3\%. We finally diagnosed the tumor as an EGIST originating from the lesser omentum.

According to Joensuu's classification, the size was 70 $\mathrm{mm}$ (over $50 \mathrm{~mm}$ ) and the location of the tumor was "nongastric," we considered this tumor high-risk [4]. Then, to determine the indication of adjuvant therapy, we performed a genetic examination of the tumor, which revealed no KIT mutation but instead revealed a PDGF $R A D 842 \mathrm{~V}$ substitution. Based on a previous report that imatinib was less effective against GIST with a PDGFRA $D 842 \mathrm{~V}$ mutation [2], adjuvant imatinib therapy was not indicated for the present patient. Instead, the patient has been carefully followed up by CT examination every 6 months and remains free of recurrence for 29 months after surgery.

\section{Discussion}

GISTs are specific mesenchymal tumors that are considered to originate from the interstitial cells of Cajal (ICCs), the pacemaker of the peristaltic movement of the GI tract [5]. Hence, they usually occur throughout the length of the GI tract, from the esophagus to the anus. However, there are GISTs arising in sites other than the GI tract, such as the omentum, mesentery, and retroperitoneum. Those GISTs are called EGIST [3].

GIST is a relatively rare tumor, which occurs in 6.814.5 cases per million people per year [6]. The common primary sites for GIST are the stomach (60-70\%), jejunum (25-30\%), colorectum (5-15\%), and duodenum $(5 \%)[7,8]$. EGISTs are estimated less than $10 \%$ of all GISTs, and they occur in the mesentery $(7.7-29.4 \%)$, retroperitoneum (25.5-25.6\%), and omentum (7.7-15.7\%) $[3,9,10]$. Hence, it is suggested that this case, EGIST in the omentum, seems to be extremely rare.

Some studies have reported that there are similar epidemiological and histological findings between GIST and EGIST $[9,11]$. We searched all articles on EGIST in the PubMed database, published up to December 2019 using the following keywords: extra-gastrointestinal stromal tumor, EGIST, gastrointestinal stromal tumor, GIST, omental, and omentum. We also examined the reference sections of published articles. We excluded articles with obvious irrelevance and finally acquired and reviewed 57 cases of omental EGIST from 25 series of small case series and case reports. The characteristics of

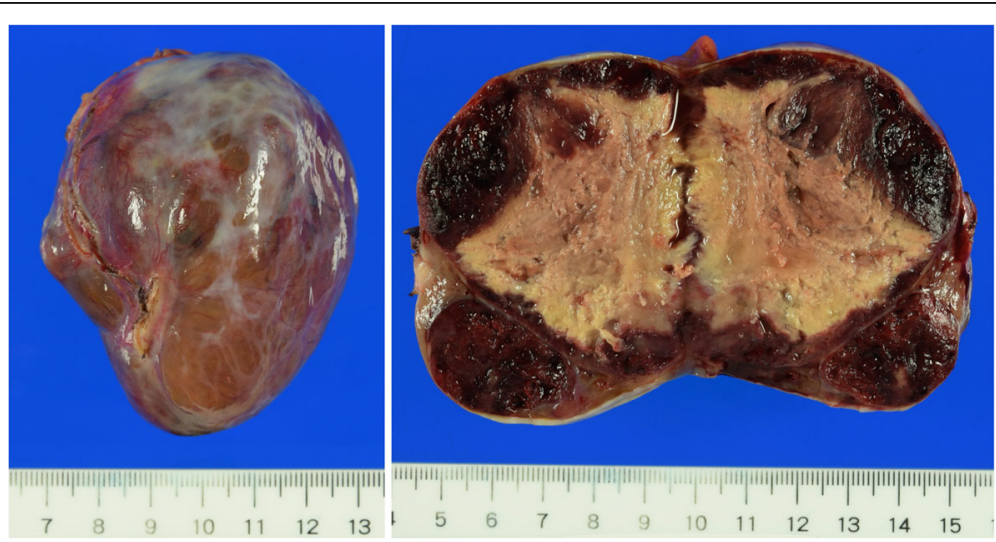

Fig. 2 Macroscopic tumor findings. The tumor was very close to the stomach; however, the pseudocapsule of the tumor was fully kept without rupture and the resected specimen did not contain any gastric component. The tumor had a smooth surface and consisted of a solid component with extensive hemorrhage and degeneration 


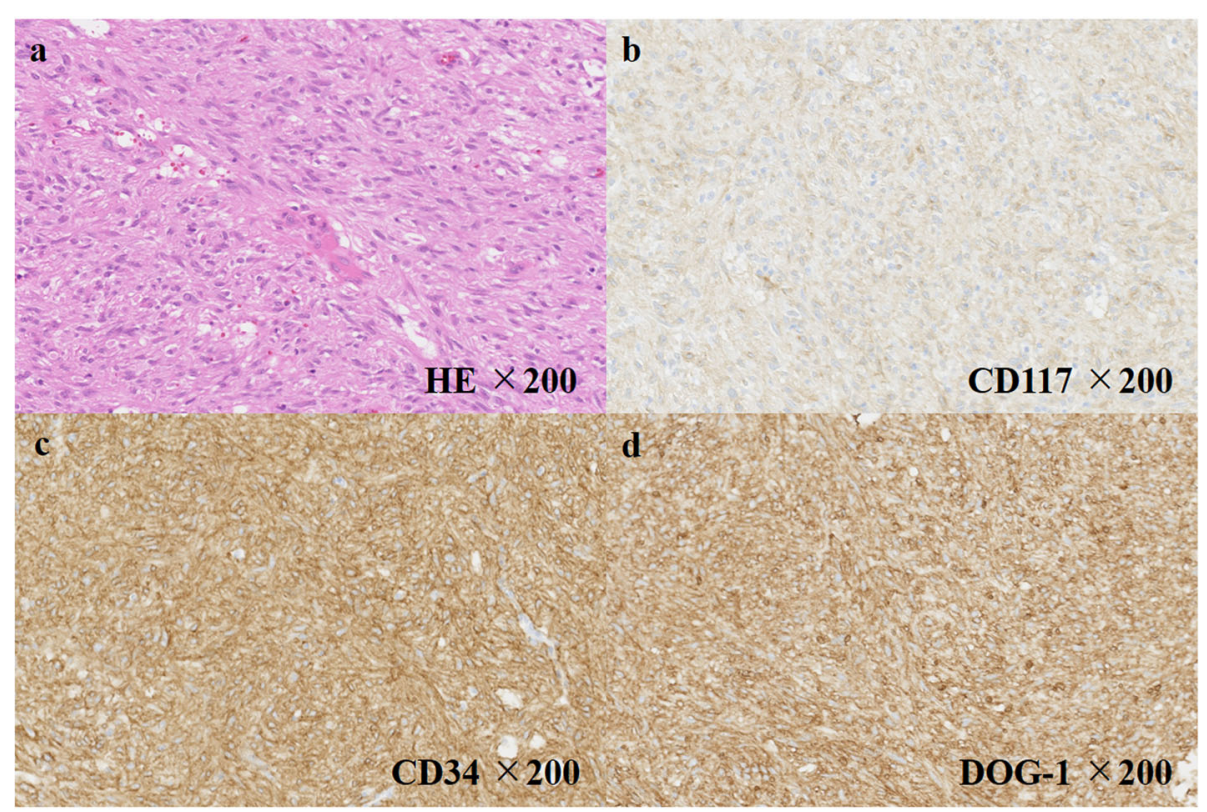

Fig. 3 Histological and immunohistochemical tumor findings. Hematoxylin and eosin (HE) staining showing spindle-shaped tumor cells (a). Positive immunohistochemistry for KIT (b), CD34 (c), and DOG-1 (d)

these cases were summarized and compared with whole GIST in Table $1[6,10,12-35]$. The age at onset, gender ratio, and histological form of omental EGIST were very similar to those of GIST.

$K I T$ and/or PDGFRA mutations are thought to be the main drivers of GIST [2]. About $80 \%$ of GISTs have KIT mutations, of which the most common are in-frame deletions or insertions or missense mutations within the juxtamembrane domain (exon 11). And 10\% of GIST have PDGFRA mutations, which commonly affect the TK2 domain (exon 18) [2, 36-38]. However, some reports showed that the proportion of these mutations depends on the location of GIST [7, 39]. In particular, among the exon 18 mutations, the $D 842 \mathrm{~V}$ substitution is limited to GIST of the stomach [2, 36-38]. Also, in EGIST, the degree of KIT and PDGFRA mutations varies on where the location of the tumor is [3]. Namely, it is suggested that omental EGIST is similar to gastric GIST, mesenteric is similar to intestinal, and retroperitoneal can take either gastric or intestinal characteristics [11]. Within 57 omental EGIST cases we reviewed this time, 25 cases described about gene mutation; gene mutations of these cases were summarized and compared with GIST of other organs in Table 2 [7, 10, 14, 17, 19, 21, 24-26, 28, 39]. Mutation status in omental EGIST was very similar to gastric GIST. In particular, PDGFRA $D 842 \mathrm{~V}$ mutation rate of omental EGIST seemed comparable with gastric GIST. These results suggested that omental EGIST is strongly related to gastric GIST, so the behavior of omental EGIST might be akin to gastric GIST.

These results may provide some suggestions into the question of where omental EGIST originates. There are some hypotheses about the origin of EGIST: (1) they are derived from extraintestinal undifferentiated mesenchymal

Table 1 Clinicopathological findings of patients with omental extra-gastrointestinal stromal tumors $(n=57)[6,10,12-35]$

\begin{tabular}{lll}
\hline & Omental EGIST $(n=57)$ & Whole GIST \\
\hline Age (years, median, range) & $63(27-89)$ & $60 \mathrm{~s}$ \\
Sex (male/female) & $32 / 25(1.28: 1)$ & $1: 1$ \\
Tumor size (cm, median, range) & $15(1-36)$ & - \\
Histologic morphology & & $70 \%$ \\
$\quad$ Spindle & $30(53.6 \%)$ & $20 \%$ \\
$\quad$ Epithelioid & $16(28.6 \%)$ & $10 \%$ \\
$\quad$ Mixed & $8(14.3 \%)$ & - \\
$\quad$ Myxoid & $2(3.6 \%)$ & - \\
\hline
\end{tabular}


Table 2 Mutation subtypes according to the primary location of GIST [7, 10, 14, 17, 19, 21, 24-26, 28, 39]

\begin{tabular}{|c|c|c|c|c|}
\hline Genetic type & Whole GIST (\%) & Gastric GIST (\%) & Intestinal GIST (\%) & Omental GIST (our review) \\
\hline KIT mutation & 77 & 65.2 & 79.7 & $60 \%(15 / 25)$ \\
\hline Exon 9 & 8 & 1.8 & 23.0 & $4 \%(1 / 25)$ \\
\hline Exon 11 & 67 & 61.4 & 54.0 & $56 \%(14 / 25)$ \\
\hline Exon 13 & 1 & 1.2 & 2.3 & - \\
\hline Exon 17 & 1 & 0.8 & 0.4 & - \\
\hline PDGFRA mutation & 10 & 22.9 & 1.2 & $28 \%(7 / 25)$ \\
\hline Exon 12 & 1 & 3.1 & 0 & $8 \%(2 / 25)$ \\
\hline Exon 14 & $<1$ & 0.5 & 0.4 & - \\
\hline Exon 18 (D842V) & 5 & 19.3 & 0.8 & $20 \%(5 / 25)$ \\
\hline Wild type & 13 & 11.9 & 19.1 & $20 \%(5 / 25)$ \\
\hline
\end{tabular}

cells capable of differentiating to ICCs [14], (2) they originate from mesenchymal undifferentiated stem cells [13], and (3) they lose the extramural contact with the intestinal wall in GISTs [40]. However, their origin remains unclear due to their rarity. Further accumulation of EGIST cases and related studies is needed.

The standard treatment for GIST without metastasis is surgical complete resection. As for EGIST also, complete resection must be the only way to cure at present. As discussed above, omental EGIST has a similar clinicopathological and genetic background to gastric GIST. However, the prognosis of EGIST, including omental EGIST, after resection is thought to be less favorable than that of GIST $[3,9,11]$. - The reason is suggested that EGIST is often found in a very large state at the onset [9-11]. In fact, as shown in Table 1, the median tumor diameter at the onset of omental EGIST was $15 \mathrm{~cm}$, extremely large. Because EGIST is not exposed to the GI tract, it is unlikely to show symptoms such as bleeding into the digestive tract or stenosis, and then the tumor detection tends to be delayed. And the larger the tumor grows, the worse some parameters predicting the prognosis, such as mitotic activity, cellularity, nuclear atypia, and necrosis, become, so it is convincing that the prognosis of EGIST, which is often found in larger states, is worse than that of GIST [27, 35].

The risk factors for recurrence of GIST are tumor size in the largest dimension $>5 \mathrm{~cm}$ and mitotic count $>5$ per $50 \mathrm{HPF}$ [2]. For GIST belonging to these high-risk groups, postoperative adjuvant imatinib therapy is known to improve prognosis $[41,42]$. However, the response of GISTs to imatinib treatment depends on the mutation status. While most GISTs are sensitive to imatinib, those with PDGFRA D842V substitutions (exon 18) are resistant to imatinib [43, 44]. There is a report that the recurrence-free survival after curative resection in patients with PDGFRA mutations was more favorable than in patients with KIT mutations [37]. Owing to imatinib resistance and favorable prognosis, patients with GIST bearing PDGFRA D842V substitutions are not generally considered to be candidates for adjuvant imatinib therapy $[44,45]$. As for EGIST, prognostic data is scarce and reported mutations are even more limited; hence, there is no consensus regarding the recommendations for adjuvant imatinib for this tumor. Prognosis of 5 cases who bare PDGFRA D842V substitutions in our review was 4-120 months (median 38 months) without recurrence and mortality. The prognosis seemed to be not so bad; however, the number of the cases was too small. Further studies are required to identify the risk factors of EGIST recurrence. At present, it is at best to deduce the results of GIST and apply them to EGIST.

In this case, we observed a mitotic count of $<1$ per 50 HPF and Ki-67 labeling index of 3.3\%. The estimated risk of tumor recurrence from these factors seemed to be relatively low $[2,46]$. However, we emphasized the fact that the tumor was relatively large in $70 \mathrm{~mm}$ diameter $(>50 \mathrm{~mm}$ ) and the tumor was EGIST (located outside the GI tract); we regarded this case as high-risk. As mentioned above, omental EGIST has a certain number of PDGFRA mutations; we previously performed a genomic examination to determine the indication of adjuvant therapy. Then, PDGF $R A D 842 V$ substitutions were shown; this tumor was expected to be resistant to imatinib. Thus, the patient was not considered to be a candidate for adjuvant imatinib and was instead followed up frequently. Some TK inhibitors, such as avapritinib and crenolanib, had shown certain potent activities for GIST with PDGFRA mutations [47]. Early development of these drugs is expected.

\section{Conclusion}

We described an extremely rare case of EGIST arising in the lesser omentum with a PDGFRA mutation. Our review showed that there were many clinicopathological and genetic similarities between omental EGIST and gastric GIST. However, the prognosis of omental EGIST was rather poorer than that of gastric GIST; much about EGIST, such as its origin and the effects of imatinib, still remains unknown. Further research is required. 


\section{Abbreviations}

GIST: Gastrointestinal stromal tumor; GI: Gastrointestinal; PDGFRA: Plateletderived growth factor receptor alpha; TK: Tyrosine kinase; EGIST: Extragastrointestinal stromal tumor; EGD: Esophagogastroduodenoscopy; EUS: Endoscopic ultrasonography; CT: Computed tomography; HE: Hematoxylin-eosin; HPF: High-power fields; DOG-1: Discovered on GIST-1; ICC: Interstitial cells of Cajal

\section{Acknowledgements}

Not applicable

\section{Authors' contributions}

KK, YY, KD, TW, TH, SO, TY, and HK were involved in the determination of treatment strategy and patient management. KK and $Y Y$ decided manuscript conception, and TY and TN advised the process of determination of manuscript conception. KK and SS drafted the pathological part of the manuscript. $Y Y$ and TH drafted the medical treatment part of the manuscript. YY drafted the manuscript and revised it critically for important intellectual content. All authors read and approved the final manuscript.

\section{Funding}

Not applicable

\section{Availability of data and materials}

All data generated during this study are included in this published article.

\section{Ethics approval and consent to participate}

This study was performed in accordance with the principles of the Declaration of Helsinki. The requirement for ethical approval was waived by the National Cancer Center Institutional Review Board.

\section{Consent for publication}

Written informed consent was obtained from the patient for publication of this case report and accompanying images.

\section{Competing interests}

The authors declare that they have no competing interests.

\section{Author details}

'Gastric Surgery Division, National Cancer Center Hospital, 5-1-1 Tsukiji, Chuo-ku, Tokyo 104-0045, Japan. ${ }^{2}$ Head and Neck Medical Oncology Division and Gastrointestinal Medical Oncology Division, National Cancer Center Hospital, 5-1-1 Tsukiji, Chuo-ku, Tokyo 104-0045, Japan. ${ }^{3}$ Division of Pathology and Clinical Laboratories, National Cancer Center Hospital, 5-1-1 Tsukiji, Chuo-ku, Tokyo 104-0045, Japan.

\section{Received: 11 April 2020 Accepted: 17 July 2020}

\section{Published online: 23 July 2020}

\section{References}

1. Miettinen M, Lasota J. Gastrointestinal stromal tumors--definition, clinical histological, immunohistochemical, and molecular genetic features and differential diagnosis. Virchows Arch. 2001;438:1-12.

2. Rubin BP, Heinrich MC, Corless CL. Gastrointestinal stromal tumour. Lancet. 2007:369:1731-41.

3. Yi JH, Park BB, Kang JH, Hwang IG, Shin DB, Sym SJ, Ahn HK, Lee SI, Lim DH, Park KW, et al. Retrospective analysis of extra-gastrointestinal stromal tumors. World J Gastroenterol. 2015;21:1845-50.

4. Joensuu H. Risk stratification of patients diagnosed with gastrointestinal stromal tumor. Hum Pathol. 2008;39:1411-09.

5. Wang X, Mori I, Tang W, Utsunomiya H, Nakamura M, Nakamura Y, Zhou G, Kakudo K. Gastrointestinal stromal tumors: are they of Cajal cell origin? Exp Mol Pathol. 2002;72:172-7.

6. Akahoshi K, Oya M, Koga T, Shiratsuchi Y. Current clinical management of gastrointestinal stromal tumor. World J Gastroenterol. 2018;24:2806-17.

7. Barnett CM, Corless CL, Heinrich MC. Gastrointestinal stromal tumors: molecular markers and genetic subtypes. Hematol Oncol Clin North Am. 2013;27:871-88.

8. Theiss L, Contreras CM. Gastrointestinal stromal tumors of the stomach and esophagus. Surg Clin North Am. 2019;99:543-53.
9. Apostolou KG, Schizas D, Vavouraki E, Michalinos A, Tsilimigras DI, Garmpis N, Damaskos C, Papalampros A, Liakakos T. Clinicopathological and molecular factors, risk factors, treatment outcomes and risk of recurrence in mesenteric and retroperitoneal extragastrointestinal stromal tumors. Anticancer Res. 2018;38:1903-9.

10. Yamamoto H, Oda Y, Kawaguchi K, Nakamura N, Takahira T, Tamiya S, Saito T, Oshiro Y, Ohta M, Yao T. Tsuneyoshi M: c-kit and PDGFRA mutations in extragastrointestinal stromal tumor (gastrointestinal stromal tumor of the soft tissue). Am J Surg Pathol. 2004;28:479-88.

11. Agaimy $A$, Wünsch $P H$. Gastrointestinal stromal tumours: a regular origin in the muscularis propria, but an extremely diverse gross presentation. A Review of 200 Cases to Critically Re-Evaluate the Concept of So-Called ExtraGastrointestinal Stromal Tumours. Langenbecks Arch Surg. 2006;391:322-9.

12. Takahashi T, Kuwao S, Yanagihara M, Kakita A. A primary solitary tumor of the lesser omentum with immunohistochemical features of gastrointestinal stromal tumors. Am J Gastroenterol. 1998;93:2269-73.

13. Miettinen M, Monihan JM, Sarlomo-Rikala M, Kovatich AJ, Carr NJ, Emory TS, Sobin LH. Gastrointestinal stromal tumors/smooth muscle tumors (GISTS) primary in the omentum and mesentery: clinicopathologic and immunohistochemical study of 26 cases. Am J Surg Pathol. 1999;23:1109-18.

14. Sakurai S, Hishima T, Takazawa Y, Sano T, Nakajima T, Saito K, Morinaga S, Fukayama M. Gastrointestinal stromal tumors and KIT-positive mesenchymal cells in the omentum. Pathol Int. 2001;51:524-31.

15. Fukuda H, Suwa T, Kimura F, Sugiura T, Shinoda T, Kaneko K. Gastrointestinal stromal tumor of the lesser omentum: report of a case. Surg Today. 2001;31: $715-8$.

16. Suzuki K, Kaneko G, Kubota K, Horigome N, Hikita H, Senga O, Miyakawa M, Shimojo H, Uehara T, Itoh N. Malignant tumor, of the gastrointestinal stromal tumor type, in the greater omentum. J Gastroenterol. 2003;38:985-8.

17. Sakurai S, Hasegawa T, Sakuma Y, Takazawa Y, Motegi A, Nakajima T, Saito K, Fukayama M, Shimoda T. Myxoid epithelioid gastrointestinal stromal tumor (GIST) with mast cell infiltrations: a subtype of GIST with mutations of platelet-derived growth factor receptor alpha gene. Hum Pathol. 2004;35: 1223-30.

18. Caricato M, Ausania F, Valeri S, Rabitti C, Tonini G, Coppola R. An omental mass: any hypothesis? Colorectal Dis. 2005;7:417-8.

19. Todoroki T, Sano T, Sakurai S, Segawa A, Saitoh T, Fujikawa K, Yamada S, Hirahara N, Tsushima Y, Motojima R, Motojima T. Primary omental gastrointestinal stromal tumor (GIST). World J Surg Oncol. 2007;5:66.

20. Gun BD, Gun MO, Karamanoglu Z. Primary stromal tumor of the omentum: report of a case. Surg Today. 2006;36:994-6.

21. Kim JH, Boo YJ, Jung CW, Park SS, Kim SJ, Mok YJ, Kim SD, Chae YS, Kim CS. Multiple malignant extragastrointestinal stromal tumors of the greater omentum and results of immunohistochemistry and mutation analysis: a case report. World J Gastroenterol. 2007;13:3392-5.

22. Franzini C, Alessandri L, Piscioli I, Donato S, Faraci R, Morelli L, Del Nonno F, Licci S. Extra-gastrointestinal stromal tumor of the greater omentum: report of a case and review of the literature. World J Surg Oncol. 2008;6:25.

23. Castillo-Sang M, Mancho S, Tsang AW, Gociman B, Almaroof B, Ahmed MY. A malignant omental extra-gastrointestinal stromal tumor on a young man: a case report and review of the literature. World J Surg Oncol. 2008;6:5012.

24. Terada T. Primary multiple extragastrointestinal stromal tumors of the omentum with different mutations of c-kit gene. World J Gastroenterol. 2008;14:7256-9.

25. Dedemadi G, Georgoulis G, Kontopanos D, Anagnostou E, Morphopoulos G, Emile JF, Christopoulos C. Extragastrointestinal stromal tumors of the omentum: review apropos of a case with a novel gain-of-function KIT mutation. J Gastrointest Cancer. 2009;40:73-8.

26. Zheng S, Huang KE, Tao DY, Pan YL. Gene mutations and prognostic factors analysis in extragastrointestinal stromal tumor of a Chinese three-center study. J Gastrointest Surg. 2011;15:675-81.

27. Mouaqit O, Jahid A, Ifrine L. Omar El Malki H, Mohsine R, Mahassini N, Belkouchi A: Primary omental gastrointestinal stromal tumors. Clin Res Hepatol Gastroenterol. 2011;35:590-3.

28. Kim KH, Nelson SD, Kim DH, Choi KU, Kim SJ, Min KW, Jang KS, Paik SS, Oh YH, Chae SW, et al. Diagnostic relevance of overexpressions of PKC-theta and DOG-1 and KIT/PDGFRA gene mutations in extragastrointestinal stromal tumors: a Korean six-centers study of 28 cases. Anticancer Res. 2012:32:923-37.

29. Ogawa H, Gotoh K, Yamada T, Takahashi H, Ohigashi H, Nagata S, Tomita Y, Yano M, Ishikawa O. A case of KIT-negative extra-gastrointestinal stromal tumor of the lesser omentum. Case Rep Gastroenterol. 2012;6:375-80. 
30. Fagkrezos D, Touloumis Z, Giannila M, Penlidis C, Papaparaskeva K, Triantopoulou C. Extra-gastrointestinal stromal tumor of the omentum: a rare case report and review of the literature. Rare Tumors. 2012;4:e44.

31. Behammane H, Aggouri Y, Oussaid M, Laalim SA, Toughrai I. Ibn majdoub K. Mazaz K: Stromal tumor of the lesser omentum : a case report. Pan Afr Med J. 2014;17:236

32. Skandalos IK, Hotzoglou NF, Matsi K, Pitta XA, Kamas Al. Giant extra gastrointestinal stromal tumor of lesser omentum obscuring the diagnosis of a choloperitoneum. Int J Surg Case Rep. 2013;4:818-21.

33. Trombatore C, Palmucci S, Angelico G, Vasquez E, Petrillo G, Puleo S, Di Cataldo A. Extragastrointestinal stromal tumor of lesser omentum: a challenging radiological and histological diagnosis. Clin Imaging. 2015;39: 1123-7.

34. Dimofte MG, Porumb V, Ferariu D, Bar NC, Lunca S. EGIST of the greater omentum - case study and review of literature. Rom J Morphol Embryol. 2016;57:253-8.

35. Patnayak R, Jena A, Parthasarathy S, Prasad PD, Reddy MK, Chowhan AK, Rukamangadha N, Phaneendra BV. Primary extragastrointestinal stromal tumors: a clinicopathological and immunohistochemical study - a tertiary care center experience. Indian J Cancer. 2013;50:41-5.

36. Heinrich MC, Corless $C L$, Demetri $G D$, Blanke CD, von Mehren $M$, Joensuu $H$, McGreevey LS, Chen CJ, Van den Abbeele AD, Druker BJ, et al. Kinase mutations and imatinib response in patients with metastatic gastrointestinal stromal tumor. J Clin Oncol. 2003;21:4342-9.

37. Joensuu H, Rutkowski P, Nishida T, Steigen SE, Brabec P, Plank L, Nilsson B, Braconi C, Bordoni A, Magnusson MK, et al. KIT and PDGFRA mutations and the risk of Gl stromal tumor recurrence. J Clin Oncol. 2015;33:634-42.

38. Debiec-Rychter M, Dumez H, Judson I, Wasag B, Verweij J, Brown M, Dimitrijevic S, Sciot R, Stul M, Vranck H, et al. Use of c-KIT/PDGFRA mutational analysis to predict the clinical response to imatinib in patients with advanced gastrointestinal stromal tumours entered on phase I and II studies of the EORTC Soft Tissue and Bone Sarcoma Group. Eur J Cancer. 2004;40:689-95.

39. Wardelmann E, Hohenberger $P$, Reichardt $P$, Merkelbach-Bruse $S$, Schildhaus $\mathrm{H}-\mathrm{U}$, Büttner R: Gastrointestinal stromal tumors of the stomach. Updates and differences compared to other locations. Pathologe 2010, 31:195-198.

40. Goh BK, Chow PK, Kesavan SM, Yap WM, Chung YF, Wong WK. A singleinstitution experience with eight CD117-positive primary extragastrointestinal stromal tumors: critical appraisal and a comparison with their gastrointestinal counterparts. J Gastrointest Surg. 2009;13:1094-8.

41. Dematteo RP, Ballman KV, Antonescu CR, Maki RG, Pisters PW, Demetri GD, Blackstein ME, Blanke CD, von Mehren M, Brennan MF, et al. American College of Surgeons Oncology Group (ACOSOG) Intergroup Adjuvant GIST Study Team: Adjuvant imatinib mesylate after resection of localised, primary gastrointestinal stromal tumour: a randomised, double-blind, placebocontrolled trial. Lancet. 2009;373:1097-104.

42. Joensuu H, Eriksson M, Sundby Hall K, Hartmann JT, Pink D, Schütte J, Ramadori G, Hohenberger P, Duyster J, Al-Batran SE, et al. One vs three years of adjuvant imatinib for operable gastrointestinal stromal tumor: a randomized trial. JAMA. 2012:307:1265-72

43. Lasota J, Miettinen M. Clinical significance of oncogenic KIT and PDGFRA mutations in gastrointestinal stromal tumours. Histopathology. 2008:53:245-66.

44. Cassier PA, Fumagalli E, Rutkowski P, Schoffski P, Van Glabbeke M, DebiecRychter M, Emile JF, Duffaud F, Martin-Broto J, Landi B, et al. Outcome of patients with platelet-derived growth factor receptor alpha-mutated gastrointestinal stromal tumors in the tyrosine kinase inhibitor era. Clin Cancer Res. 2012;18:4458-64.

45. Corless CL, Schroeder A, Griffith D, Town A, McGreevey L, Harrell P, Shiraga S, Bainbridge T, Morich J, Heinrich MC. PDGFRA mutations in gastrointestinal stromal tumors: frequency, spectrum and in vitro sensitivity to imatinib. J Clin Oncol. 2005;23:5357-64.

46. Yu Z. Wenqing Hu, Ping Chen, Masanobu Abe, Lei Shi, Si-yuan Tan, Yong Li, Liang Zong: Ki67 is a biological marker of malignant risk of gastrointestinal stromal tumors: a systematic review and meta-analysis. Medicine (Baltimore). 2017;96:e7911.

47. Martin-Broto J, Moura DS. New drugs in gastrointestinal stromal tumors. Curr Opin Oncol. 2020;32:314-20.

\section{Publisher's Note}

Springer Nature remains neutral with regard to jurisdictional claims in published maps and institutional affiliations.

\section{Ready to submit your research? Choose BMC and benefit from:}

- fast, convenient online submission

- thorough peer review by experienced researchers in your field

- rapid publication on acceptance

- support for research data, including large and complex data types

- gold Open Access which fosters wider collaboration and increased citations

- maximum visibility for your research: over $100 \mathrm{M}$ website views per year

At $\mathrm{BMC}$, research is always in progress.

Learn more biomedcentral.com/submissions 